UNIO - EU Law Journal. Vol. 4, No. 1, January 2018, pp 3-15.

®2018 Centre of Studies in European Union Law

School of Law - University of Minho

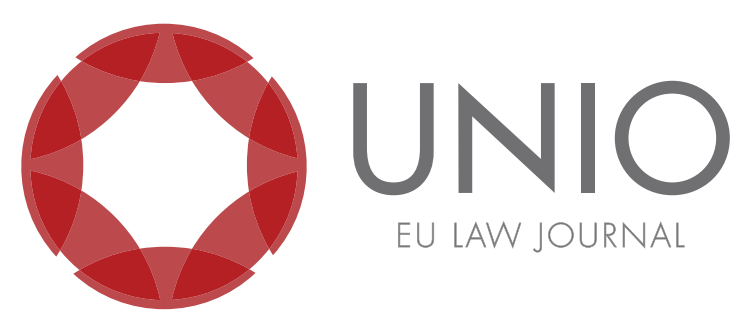

\title{
The European Union's existential crisis: current challenges from populism to Donald Trump*
}

\author{
Rita de Sousa Costa ${ }^{1}$ \\ Tiago Sérgio Cabral ${ }^{2}$
}

ABSTRACT: 2016 was marked by the rise of populism and isolationism around the world. The European Union is losing a Member State for the first time, after the British voted to leave in their "Brexit" referendum. Across the Atlantic, Donald Trump was elected President of the United States, causing concern amongst European leaders. In the remaining Member States, populist and Eurosceptic political forces are becoming more relevant, further endangering the integrity of the European Union. In this paper, we analyse the motives behind the European Union's "existential crisis", which is arguably, one of the most significant challenges the EU will face in its near future. We conclude that the European Union must reform in order to regain their citizens' trust and reinforce democracy.

KEYWORDS: European Union - Trump - Brexit - populism - financial Crisis - European integration.

\footnotetext{
*This paper is a translation of our award-winning submission to the "Professor Paulo de Pitta e Cunha 2017 Award" established by the European Institute of the University of Lisbon's Faculty of Law. No significant changes were made to the content or to the positions defended in the original. However, to avoid the unpleasant reading experience that would arise from a literal translation several linguistic adaptations were implemented. The Portuguese original is available at: https:// institutoeuropeu.eu/images/stories/documentos/Pr\%C3\%A9mio_Professor_Doutor_Paulo_ de_Pitta_e_Cunha/A_Crise_Existencial_da_Uni\% $\%$ C3\%A3o_Europeia.pdf. A short update to its content covering the aftermath of the Dutch general election, French presidential election, German federal election, Austrian legislative election, and Czech parliamentary election is available at: https:// officialblogofunio.com/2017/11/07/rose-tinted-glasses-might-prove-fatal-populists-and-theirperformances-after-the-2017-dutch-general-election/.

${ }^{1}$ Researcher at Centre of Studies in European Union Law. Email: rita@ritasousacosta.com.

${ }^{2}$ Researcher at Centre of Studies in European Union Law. Corresponding author. Email: tc@ tiagosergiocabral.com
} 


\section{A Union in crisis: the last years of European politics}

The European Union (hereinafter, EU) is experiencing times of great uncertainty. The 2008 financial crisis temporarily damaged the European economy but, more than that, it may have permanently hurt its spirit. The economic recovery - at a slower pace in the periphery countries - did nothing to mend the spiritual damage. Even before the financial crisis, other events started the EU's "existential crisis", ${ }^{3}$ like the failure of the European Constitution due to its rejection in the French and Dutch referendums. Recently, the refugee crisis and a plethora of terrorist attacks further complicated the situation. Moreover, the EU is losing a Member State for the first time in its history and may face hostility from the current American administration.

The periphery countries were particularly ravaged by the effects of the financial crisis. The derogatory designation of "P.I.G.S" was attributed to the most affected States (Portugal, Ireland, Greece and Spain). Among those, the Greek situation was particularly serious. Economic adjustment programmes had to be implemented when the severe increase in the spread of government bonds made these countries unable to secure financing in the international markets. The Portuguese economic adjustment programme, the "Memorandum of Understanding on Specific Economic Policy Conditionality", ${ }^{4}$ whose signatories were Portugal, the European Commission (EC), the International Monetary Fund (IMF) and the European Central Bank (ECB) required deep structural reforms. Some of these reforms were successful like the flexibilization of the public sector, while others failed catastrophically and contributed for the depopulation of the country's interior and originated more social and economic inequality. $16,2 \%$ of the workforce was unemployed in $2013 .{ }^{5}$ The emigration of highly qualified young professionals, who could easily find abroad the professional opportunities that Portugal was not able to provide, became a pressing issue for the country. Portuguese citizens became outraged by the successive downgrades to the credit ranking of the national debt. When it fell to speculative-grade or "junk status" a group of Portuguese hackers hacked the Moody's website ${ }^{6}$ and a video was prepared to explain to the rating agencies and to the United States President Barack Obama why "Portugal is not junk". In the academy, a question arose: "Is austerity the cure... or the disease?".

In the EU, the southern countries were satirised as poor and lazy in contrast with the hard-working and rich northern countries. ${ }^{9}$ The values of European loyalty and

\footnotetext{
3 The "diagnosis" comes from the President of the European Commission Jean-Claude Juncker himself, in his 2016 State of the Union Address. See "Speech: State of the Union Address 2016: Towards a better Europe - a Europe that protects, empowers and defends", European Commission, accessed Mar 1, 2017, http:/ / europa.eu/rapid/press-release_SPEECH-16-3043_en.htm.

4 See "Memorandum of Understanding on Specific Economic Policy Conditionality", European Commission, accessed Feb. 27, 2017, http://ec.europa.eu/economy_finance/eu_borrower/ mou/2011-05-18-mou-portugal_en.pdf.

${ }^{5}$ See "Unemployment rate: total and by sex (\%)", Pordata, accessed Mar. 3, 2017, http://www.pordata. $\mathrm{pt} / \mathrm{en} /$ Portugal/Unemployment+rate+total+and+by+sex+(percentage)-550.

'See João Pedro Pereira, “Cidadãos portugueses' usam site da Moody’s para mensagem provocatória”, Público, July 7 2011, accessed Feb. 27, 2017, https://www.publico.pt/2011/07/07/economia/noticia/ cidadaos-portugueses-usam-site-da-moodys-para-mensagem-provocatoria-1501890.

7 See "Portugal não é lixo", Unattributed Author, accessed Mar 3, 2017, https://www.youtube.com/ watch?v=1aZ1ZyGRjiM, accessed 3 Mar 2017.

${ }^{8}$ See Eduardo Paz Ferreira, A Austeridade Cura... A Austeridade Mata?(Lisboa: AAFDL, 2016).

9 See Eduardo Paz Ferreira, "Endividamento e Soberania Nacional", in A Crise e o Direito, eds. Jorge Bacelar Gouveia e Nuno Piçarra (Coimbra: Almedina, 2013), 121-135.
} 
solidarity became secondary in the face of economic hardships. The free movement of persons, goods, services and capital (four fundamental freedoms) are at the very core of the EU's spirit and are enshrined in both the Treaty on European Union (TEU) and the Treaty on the Functioning of the European Union (TFEU). However, anti-EU forces in the northern countries cultivated the idea that the citizens of the southern and eastern countries would "steal their jobs". A new wave of nationalism and populism emerged masterfully using the EU and the other Member States as scapegoats for national issues. In the "poor" countries, the EU was the "enemy" because of the austerity measures it had forced on them. On the other hand, in the "rich" countries, the EU was the "enemy" because it allowed the immigrants from the "poor" countries to enter unrestricted.

The "regressive tendency"10 in the most recent case law of the Court of Justice of the European Union (CJEU) reflects the uncertainty of the times. The CJEU's decisions in Dano or Alimanovic appear to be a step back from Martinez. Sala, Grzelcyyle and Zambrano, ${ }^{11}$ where European Citizenship is concerned.

There is also a heated debate between Eurosceptics and integrationists regarding the existence of a democratic deficit in the EU. Nigel Farage frequently accused the EU of being undemocratic in the campaign for the referendum in the United Kingdom (UK). When discussing this issue, the most avid integrationists usually invoke a seemingly irreproachable formal argument: the MPEs are elected to the European Parliament by direct universal suffrage (Art. 14, 3, TEU). Second, both the European Council and the Council of the European Union are elected in their Member States [Arts. 15(2) and 16(2) TUE] and the President of the European Commission is proposed by the European Council "taking into account the elections to the European Parliament and after having beld the appropriate consultations" and is "elected" in the European Parliament "by a majority of its component members" [Art. 17(7), TEU]. In theory, the argument is flawless. In practice, it is deeply flawed. The fact is that there is only one true European election, and from that election, four "democratic" institutions materialise. These institutions have the monopoly on the legislative and executive power in the EU. By comparison, in the US, at a federal level, there are separate elections for both houses of Congress and for the President of the United States. We believe that the Commission would greatly benefit from the additional legitimacy of a President that is directly elected by the citizens, like his American counterpart. ${ }^{12}$ We should also keep in mind that the influence of the European Council may go beyond what is enshrined in the Article 15, 1, TEU. ${ }^{13}$

\footnotetext{
10 See J. N. Cunha Rodrigues, "As Comunidades de 1986 e a União de 2016", in União Europeia: Reforma on Declínio?, ed. Eduardo Paz Ferreira (Lisboa: Vega, 2016), 1933; Alessandra Silveira, "Cidadania Social na União Europeia - quo vadis? Avanços e recuos entre forças de coesão e fragmentação", in União Europeia: Reforma..., 293-310. 11 See Judgment of 11 Nov. 2014, Dano, C-333/13, ECLI:EU:C:2014:2358; Judgment of 15 Sep. 2015, Alimanovic, C-67/14, ECLI:EU:C:2015:597; Judgment of 12 May 1998, Martinez Sala, C-85/96, ECLI:EU:C:1998:217; Judgment of 20 Sep. 2001, Grzelczy/k, C-184/99, ECLI:EU:C:2001:458; Judgment of 8 Mar. 2011, Zambrano, C-34/09, ECLI:EU:C:2011:124.

${ }^{12}$ In the 2015 Riga summit, Juncker greeted the Hungarian Prime Minister Viktor Orbán with a goodhumoured "Hello, dictator". Even if one dislikes Orbán's policies, it is still an ironic situation: Juncker who is not directly elected by the citizens labelling Orbán as a dictator. See “'Hello, dictator': European commission president jokes with Hungarian PM", The Guardian, accessed Feb. 27, 2017, https:// www.theguardian.com/world/video/2015/may/22/hello-dictator-european-commission-presidentjuncker-jokes-hungarian-orban-video.

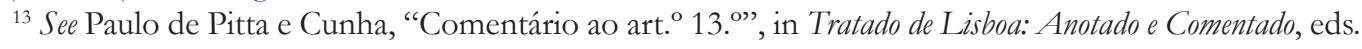
Manual Lopes Porto and Gonçalo Anastácio (Coimbra: Almedina, 2012),63-65.
} 
On 16 February, 2017, two highly relevant resolutions ${ }^{14}$ were approved by the European Parliament. The first, drafted by the MEPs Elmar Brok (PPE) and Mercedes Bresso (S\&D), ${ }^{15}$ proposes the transformation of the Council of the European Union in a "second legislative chamber" (point 29) and a more frequent use of the "passerelle rule" [Art. 48(7) TEU]. We could go further than this resolution and replace the Council of the European Union with a Senate elected by direct universal suffrage. Currently, the Council of the European Union consists "of a representative of each Member State at ministerial level'. This scenario raises two very serious issues: $i)$ the vast majority of the voters elect those representatives for the national government without even knowing that they are also electing them for the Council of the European Union. This is to be expected since national issues are a more pressing concern in the minds of the voters, thus the focus of most national political campaigns. However, one could argue that the representatives' democratic legitimacy in the EU is weakened since democracy should reflect "the will of the people". Furthermore, even if the voter is taking into consideration the election for the Council of the European Union, the method is undemocratic by design. A candidate may be an excellent pick for finance minister but the voter may find him a poor negotiator that should not represent the country in the Council of the European Union. This puts the voter in a "no win" situation, since he may either have an excellent finance minister or an excellent negotiator, never both, because they are voted as a package. In Member States where the government has no legislative powers, or has its legislative power restricted the issue is even more complicated. It does not seem reasonable for the EU to give the national representatives legislative powers when they do not have them in their own countries. It might even endanger the separation of powers in those Member States. A proper Senate would also contribute to the proximity between the voter and its elected representative in the EU. The second resolution, drafted by the MPE Guy Verhofstadt (ADLE), ${ }^{16}$ proposes a structural reform ${ }^{17}$ from where we would highlight: ii) the attribution of the right of legislative initiative to the European Parliament (point 62); ending "Europe à la carte" (points 6 through 12); iii) the "undertaking $[\mathrm{of}]$ a comprehensive, in-depth review of the Lisbon Treaty".

The White Paper on the future of Europe published by the European Commission on 1 March, 2017, forming the Commission's contribution to the Rome Summit of 25 March 2017, lists five possible scenarios for maintaining the Unity of "the EU at 27'. ${ }^{18}$ The possible scenarios for the evolution of the EU until 2025 per the Commission are: i) "carrying on" - this scenario basically maintains the status quo; ii) "notbing but the single market" - the most Eurosceptic solution which keeps the single market and removes everything else; iii) "those who want more do more" - the multi-speed Europe scenario: the

\footnotetext{
${ }^{14}$ Even if due to their nature, the resolutions of the European Parliament have limited importance.

${ }^{15}$ See "European Parliament resolution of 16 February 2017 on improving the functioning of the European Union building on the potential of the Lisbon Treaty (2014/2249(INI))", European Parliament, accessed Feb. 27, 2017, http:/ /www.europarl.europa.eu/sides/getDoc.do?type=TA\&lan guage $=$ EN\&reference $=$ P8-TA-2017-0049.

16 See "European Parliament resolution of 16 February 2017 on possible evolutions of and adjustments to the current institutional set-up of the European Union (2014/2248(INI))", European Parliament, accessed Feb. 27, 2017, http://www.europarl.europa.eu/sides/getDoc.do?pubRef=-// $\mathrm{EP} / / \mathrm{TEXT}+\mathrm{TA}+\mathrm{P} 8-\mathrm{TA}-2017-0048+0+\mathrm{DOC}+\mathrm{XML}+\mathrm{V0} / / \mathrm{EN}$.

${ }^{17}$ The implementation of some of the proposals in the resolution would require amendments in the TEU and TFEU.

${ }^{18}$ See "Commission presents White Paper on the future of Europe: Avenues for unity for the EU at 27”, European Commission, accessed Mar. 1, 2017, http://europa.eu/rapid/press-release_IP-17385_en.htm.
} 
Member States may integrate at their own pace; $\left.{ }^{19} i v\right)$ "doing less more efficiently" - the EU intervenes less but in a more effective and united manner; $v$ ) "doing much more together" further integration and a more interventive EU. All the Member States commit equally. The lack of substance in the "White Paper" is truly disappointing. The Commission lists the possible scenarios for the future that were already known to the public, offering no contribution or new path to the EU's development.

\section{2016 in two chapters}

Two events in the year of 2016 changed the World's political landscape: "Leave's" victory in the "United Kingdom European Union membership referendum" and Donald Trump's victory in the United States Presidential Election. Usually, the discussion of these events focused on finding out "bow" and "bow much" these events will change the status quo. However, one should not forget that these events already changed the status quo and are themselves, a reflection of previous changes in our world. Therefore, it is of extreme importance that we first understand the past and present if we wish to predict the future.

\subsection{Chapter I: until the referendum tears us apart}

On 23 June 2016, a political earthquake with its epicentre in the UK hit the EU. Against all predictions, the British people voted to leave the EU. "Leaves" victory in the referendum was not overwhelming $(51.9 \%$ against $48.1 \%)$ but it was convincing. The high turnout $(72.2 \%)$ assured that there is no room to question the democratic legitimacy of the referendum.

At the beginning of the night, practically no one was expecting such a result. Exit polls gave a 4\% lead to "remain" and Nigel Farage conceded defeat. ${ }^{20}$ However, a few disappointing results in traditionally euro-enthusiastic parts of the country and a high turnout in more conservative ones quickly turned the tide in brexit's favour.

The referendum's results broke the UK in two. Scotland and Northern Ireland voted "remain" by wide margins whereas Wales and England voted "leave". ${ }^{21}$ In the aftermath, the Prime Minister David Cameron resigned. Cameron had called the referendum as a political move to ensure his re-election, but he did not expect to lose it. A petition signed by more than 4 million people requested a second referendum on the matter but was quickly rejected by the new cabinet, led by Theresa May. ${ }^{22} \mathrm{~A}$ decision by the Supreme Court of the United Kingdom ${ }^{23}$ requiring the government

\footnotetext{
${ }^{19}$ Germany, France, Italy and Spain expressed their preference for this solution. See Edouard Pflimlin, "Sommet de Versailles: pour une UE à plusieurs vitesses". Le Monde, March 7, 2017, accessed Mar 7, 2017, http://www.lemonde.fr/europe/article/2017/03/07/sommet-de-versailles-pour-une-ue-aplusieurs-vitesses_5090248_3214.html\#fbma7QBj0EGrBX1z.99.

${ }^{20}$ See "YouGov poll puts Remain ahead with 52\%", Financial Times, accessed Feb. 25, 2017, https:// www.ft.com/content/d5ef0b36-c642-3f23-8e40-b13903f73815.

${ }^{21}$ See Tim Oliver, "The world after Brexit: From British referendum to global adventure", International Politics 53,6 (2016): 689-707.

${ }^{22}$ See "EU Referendum: Results", BBC News, accessed Feb. 27, 2017, http:/ /www.bbc.com/news/ politics/eu_referendum/results; Nicola Harley, "Brexit: Government rejects petition signed by 4 million calling for second EU referendum", The Telegraph, Jul 09, 2016, accessed Mar. 2, 2017, http:/ / www.telegraph.co.uk/news/2016/07/09/brexit-government-rejects-petition-for-secondreferendum; Rishi Iyengar, “Britain's David Cameron Resigns After Vote to Leave E.U.”, Jun. 24, 2016, accessed Mar. 1, 2017, http://time.com/4381193/david-cameron-resigns-brexit-vote.

${ }^{23}$ See R (on the application of Miller and Dos Santos) v. Secretary of State for Exiting the European
} 
to get parliamentary approval before triggering Article 50 of the TEU caused further disagreements in UK's public opinion. ${ }^{24}$ Some supporters of Brexit were furious with the decision, even calling the judges "enemies of the people". ${ }^{25}$ Following the Court's decision, the House of Commons approved the European Union (Notification of Withdrawal) Bill quickly and by a wide majority. The bill was met with greater opposition in the House of Lords, where it was amended to give Parliament a "meaningful vote" on the final deal between the EU and the UK and to ensure the protection of the rights of the three million EU citizens living in the UK. ${ }^{26}$ In a stroke of legislative irony, the unelected House of Lords seems adamant in protecting parliamentary sovereignty while the House of Commons promptly gave the government absolute power. In the end, the Lords will probably relent but the amendments might trigger a "parliamentary ping-pong" between the Houses and delay the government's plan to trigger Article 50 by the end of March 2017.

Even if it is not in the government's designated timeframe, these internal struggles will be overcome. After that, the UK and the EU must negotiate the terms of their separation. It may be an "amicable divorce" where the economic and social effects of the UK leaving are reduced by it joining the European Economic Area (EEA). On the opposite end of the spectrum, there is the option of a hard Brexit with no trade deal between the UK and the EU. The UK and the EU would engage in trading according to the rules of the World Trade Organization (WTO). In between these scenarios, in abstract, we could also have the "Swiss Model" (EFTA but not EEE), the "Turkish Model" (Customs Union) and the option of building a completely new trade deal. ${ }^{27}$ At the time of writing, the unwillingness of both parties to compromise on the issue of free movement of persons points to a hard Brexit. Nevertheless, since negotiations have not begun, it is not possible to predict with any degree of certainty. ${ }^{28}$

The UK always viewed European integration with a certain degree of scepticism. ${ }^{29}$

Union and associated references, Supreme Court of the United Kingdom, 2017.

${ }^{24}$ See "Brexit, The Supreme Court (UK) and the principle of loyalty: on the question of irrevocability of a withdrawal notice", Alessandra Silveira, accessed Feb. 27, 2017, https://officialblogofunio. $\mathrm{com} / 2017 / 01 / 26 /$ brexit-the-supreme-court-uk-and-the-principle-of-loyalty-on-the-question-ofirrevocability-of-a-withdrawal-notice; "R (Miller) v The Secretary of State for Exiting the European Union [2016] EWHC 2768 (Admin): Realpolitik and the Revocation of an Article 50 TEU Notification to Withdraw", John Cotter, accessed Feb. 27, 2017, https://officialblogofunio.com/2016/12/02/rmiller-v-the-secretary-of-state-for-exiting-the-european-union-2016-ewhc-2768-admin-realpolitik-andthe-revocation-of-an-article-50-teu-notification-to-withdraw:

${ }^{25}$ See Claire Phipps, "British newspapers react to judges' Brexit ruling: 'Enemies of the people", The Guardian, Nov. 4, 2016, accessed Mar. 1, 2017, https://www.theguardian.com/politics/2016/ nov/04/enemies-of-the-people-british-newspapers-react-judges-brexit-ruling.

${ }^{26}$ See "European Union (Notification of Withdrawal) Bill 2016-17: Progress of the Bill", UK Parliament, accessed March 1, 2017, http://services.parliament.uk/bills/2016-17/ europeanunionnotificationofwithdrawal.html.

${ }^{27}$ See M. Hachula et al, Uncertainty after the Brexit vote: Economic effects and legal aspects (Brussels: European Parliament, 2016), accessed Mar. 1, 2017, https://polcms.secure.europarl.europa.eu/cmsdata/ upload/cab9f86d-9888-40e6-b2c9-b6418c699fe4/DIW.pdf.

${ }^{28}$ See C. Barnard, "The voters have spoken. Brexit it is", UNIO EU Law Journal - The Official Blog: Thinking \& Debating Europe, Ago. 4, 2016, accessed Feb. 27, 2017, https://officialblogofunio. com/2016/08/04/the-voters-have-spoken-brexit-it-is/. C. Barnard, A. Ludlow, "Free Movement of Services, Migration and Leaving the EU", National Institute Economic Review, 236, 1 (2016): 23-30. V. Bogdanor, "Brexit, the Constitution and the Alternatives", King's Law Journal, 27, 3 (2016): 314-322. ${ }^{29}$ See C. Gifford, "The United Kingdom's Eurosceptic political economy", The British Journal of Politics and International Relations, 18, 4 (2016): 779-794. A. Glencross, Why the UK Voted for Brexit: David Cameron's Great Miscalculation, (Birmingham: Palgrave Macmillan, 2016). S. Hobolt, "The Brexit vote: a 
Several exceptions had to be built in the European legal framework to accommodate the UK's demands. It is not part of the Eurozone and of the Schengen Area. British scepticism might not be scepticism of just the EU but also, of Europeans in general and of immigration. ${ }^{30}$ Without it, the EU may find it easier to achieve further integration. But only if it can overcome its "existential crisis", caused by the populist wave that has swept across the EU. ${ }^{31}$

Leaving the biggest trade bloc in the world will surely have economic consequences. Since the referendum, the British Pound has been falling against other major currencies. At the time of writing, 1,00£, is worth less than 1,20€ and 1,25\$. Before the referendum, it was worth $1,30 €$ and $1,47 \$$. As of result of Pound's decline in value, companies who export to the UK had to raise prices. Microsoft's readjustment of prices may cost millions to taxpayers. ${ }^{32}$ Unilever also raised Marmite's prices, causing disputes between the manufacturer and some retailers. ${ }^{33}$ One could argue that a weaker Pound would help exports from the UK and thus, reduce Brexit's negative effects. While it may happen in theory, its effect will not probably be enough to counterbalance the negative effect that leaving with no deal would have on the economy. In that regard, the initial resistance of the British economy seems to be finally subsiding. ${ }^{34}$ Nevertheless, we should wait for the official negotiations to begin and then make the analysis of the economic effects in both economies. ${ }^{35}$

Taking back control of British laws might not be immediately possible. European Legislation constitutes a crucial part of the UK's legal framework. The British government plans on "converting directly effective EU law into UK law, and preserving secondary legislation enacted under the ECA"36 amending it in accordance with the country's needs

divided nation, a divided continent", Journal of European Public Policy, 23, 9 (2016): 1259-1277. T. Oliver, "Fifty Shades of Brexit: Britain's EU Referendum and its Implications for Europe and Britain", The International Spectator - Italian Journal of International Affairs, Online first, (2017): 1-11.

${ }^{30}$ See M. Freeden, "Editorial. After the Brexit referendum: revisiting populism as an ideology", Journal of Political Ideologies, 22, 1, (2017): pp.1-11. J. Matti, Y. Zhou, "The political economy of Brexit: explaining the vote", Applied Economics Letters, (2016): 1-4.

${ }^{31}$ See R. F. Inglehart, P. Norris, Trump, Brexit, and the Rise of Populism: Economic Have-Nots and Cultural Backlash, (Harvard Kennedy School: Faculty Research Working Paper Series, 2016). J. Clarke, J. Newman, "People in this country have had enough of experts': Brexit and the paradoxes of populism", Critical Policy Studies, (2017), in press. T. Siczek, M. R. Steenbergen, "Better the devil you know? Risktaking, globalization and populism in Great Britain", European Union Politics, (2017), in press.

32 See J. Titcomb (2016). "Microsoft to raise prices by up to 22pc after slump in pound", The Telegraph, Oct., 23, 2016, accessed Feb., 27, 2017, http://www.telegraph.co.uk/business/2016/10/23/microsoft-to-lift-prices-up-to-22pc-over-falling-pound/.

${ }^{3}$ See "Morrisons raises Marmite price by 12.5\%", BBC News, Oct. 28, 2016, accessed Feb. 27, 2017, http://www.bbc.com/news/business-37801847.

${ }^{34}$ See K. Allen, P. Scruton, "How has the Brexit vote affected the UK economy? February verdict", The Guardian, Feb. 21, 2017, accessed Feb. 27, 2017. https://www.theguardian.com/business/nginteractive/2017/feb/22/how-has-the-brexit-vote-affected-the-uk-economy-february-verdict. K. Allen, "Brexit economy: inflation surge shows impact of vote finally beginning to bite", The Guardian, Dec. 21, 2016, accessed Feb. 27, 2017, https://www.theguardian.com/business/2016/dec/21/brexiteconomy-referendum-inflation-uk-2017. "How has economy fared since Brexit vote?", BBC, Jan. 17, 2017, accessed Feb. 27, 2017, http://www.bbc.com/news/business-36956418.

35 See D. Blagen, "Britain and the world after Brexit", International Politics, 54, 1 (2017): 1-25. M. Ebell, J. Warren, "The Long-Term Economic Impact of Leaving the EU", National Institute Economic Review, 236, 1 (2016): 121-138. C. Hartwelli, R. Horvath, An assessment of the impact of Brexit on euro area stability, (Brussels: European Parliament, 2016), 7-22.

${ }^{36}$ Elliott, Tierney, "The "Great Repeal Bill" and Delegated Powers", Public Law for Everyone, Mar. 7, 2017, accessed Mar. 10, 2017, https://publiclawforeveryone.com/2017/03/07/the-great-repeal-bill- 
subsequently. This raises a very different issue since "while it is questionable as to whether or not there will ever be sufficient time or resources to undertake an adequate scrutiny, it seems that there will be plenty of time for MPs, businesses and interest groups to lobby for the selective amendment or repeal of particular laws". ${ }^{37}$ Commerce may suffer even more if the UK and EU's legal framework deviate too much. As an example, the UK may adopt lower food safety, consumer protection or data protection standards.

The EU and its Member States shall also feel deeply the effects of Brexit. The EU will lose about $5 \%$ of its budget and the remaining Member States might have to make up for it. The weaker Pound may decrease the purchasing power of British citizens, thus adversely affecting countries that export to the UK. If there is a hard Brexit, the possible re-imposition of import duties might further complicate the situation.

\subsection{Chapter II: Trump comes, sees and conquers}

In 2008, Barack Obama, a young and charismatic senator from Illinois, achieved a surprising victory over the establishment candidate in the Democratic Party Primary elections. Obama lost the popular vote to Hillary Clinton in the Primary, but the Democratic Party united around him and he was able to easily defeat John McCain to become the $44^{\text {th }}$ President of the United States. Obama is a brilliant public speaker and his message of hope and the "Yes, We Can" slogan connected with the American voter, allowing him to serve two terms in the White House and leave with an unusually high approval rating.

In 2016, Donald J. Trump, a famous billionaire and reality TV star, emerged victorious from the Republican Party Primary defeating more experienced candidates like Jeb Bush, Ted Cruz and Marco Rubio. Not unlike Obama, Trump's message connected with its electorate who wished to "Make America Great Again" ${ }^{38}$ In the

and-delegated-powers/.

${ }^{37}$ See Catharine Macmillan, "The Impact of Brexit upon English Contract Law", King's Law Journal 27,3 (2016): 420-430.

38 Trump managed to survive a plethora of political "scandals" that would have sunk most political candidates. Trump was accused of sexism, racism, xenophobia, disrespect for the military veterans and connections to the Russian government. However, not only did he survive, but arguably thrived because of the controversy surrounding his campaign. In fact, $42 \%$ of women voted for him, and his results with Afro-American / Latino voters were better than Romney's in 2012. His ability in the political arena also exceeded expectations. Jeb Bush, the initial favourite, spent 130 million dollars in campaign but did not win any state and was severely damaged by the label of "no energy" courtesy of Trump. Similarly, Marco Rubio became "Little Marco", Ted Cruz "Lyin' Ted" and Hillary Clinton "Crooked Hillary". Trump's issues with the mainstream media are also widely known. At the time of writing, he seems to be on the winning side of their dispute, since the most recent polls say that the public trusts him more than the mainstream media. Furthermore, they may have involuntarily helped in his election. See Ronald F. Inglehart and Pippa Norris, "Trump, Brexit, and the Rise of Populism: Economic Have-Nots and Cultural Backlash", Harvard Kennedy School: Faculty Research Working Paper Series (2016): 6; Pedro Madeira Froufe, “O insustentável peso democrático do populismo: deambulações em torno da União Europeia, de olhos postos em Donald Trump”, in UNIO E-book - Volume I: Workshops CEDU 2016, coord. Alessandra Silveira (Braga: CEDU, 2017): 305-315.; "Behind Trump's victory: Divisions by race, gender, education", Alec Tyson and Shiva Maniam, accessed Feb. 27, 2017, http://www.pewresearch.org/fact-tank/2016/11/09/behind-trumps-victory-divisionsby-race-gender-education; “Clinton Couldn't Win Over White Women”, Clare Malone, accessed Feb. 27, 2017, https:/ / fivethirtyeight.com/features/clinton-couldnt-win-over-white-women; Nicholas Confessore and Sarah Cohen, "How Jeb Bush Spent \$130 Million Running for President With Nothing to Show for It”, New York Times Feb. 22, 2016, accessed Feb. 27, 2017, https://www.nytimes.com/2016/02/23/us/ politics/jeb-bush-campaign.html?_r=1; Paola Chavez and Veronica Stracqualursi, "From 'Crooked Hillary' to 'Little Marco,' Donald Trump's Many Nicknames”, ABC News, May 11, 2016, accessed Feb. 27, 2017, http://abcnews.go.com/Politics/crooked-hillary-marco-donald-trumps-nicknames/story?id=39035114; 
General Election, Trump achieved a surprising victory over Hillary Clinton and thus, became the $45^{\text {th }}$ President of the United States. Like Bush in 2000, Trump won the election without winning a majority of the popular vote.

Trump's victory surprised most political analysts who did not believe that he could win the Republican Primaries much less the Presidential Election. The Huffington Post's Pollster gave him a $1.7 \%$ probability of winning. Nate Silver gave him $28.2 \%$ and almost every other mainstream analyst followed in between. ${ }^{39}$ In fact, the unusually high chances given to Trump by Nate Silver prompted accusations that he was swaying the results of the polls in Trump's favour. ${ }^{40}$ In the end, neither the Huffington Post nor Silver's "FiveThirtyEight" were right. Silver predicted that Trump's path to victory depended on victories in Florida, Nevada, North-Carolina, and New Hampshire (all unlikely). However, Trump won in Wisconsin ("FiveThirtyEight" gave him a 15,9\% probability of winning there), Michigan (19,7\%) and Pennsylvania (22,6\%) and lost Nevada and New Hampshire. ${ }^{41}$ In the betting markets, the Irish company Paddy Power was so sure of Clinton's victory that it paid early to those who betted on her. ${ }^{42}$

Trump won democratically but why? This question shall occupy political analysts for the next few years. The theories regarding the Trump's success are numerous and contradictory. We shall list some: i) "Political Correctness", also known as the "PC Culture", went too far and thus a counterculture emerged and united behind a pragmatic businessman helping him seize victory; ${ }^{43}$ ii) the Republican Party suffered a coup by an outsider; iii) the Russians influenced the elections; $i v$ ) the voters from the rural communities felt that the mainstream politicians are disconnected from their needs and thus decided to elect an outsider; $v$ ) the US population is racist, sexist and xenophobic; vi) minorities voted in inferior numbers when compared to Obama's election, thus giving an advantage to the Republican Party; vi) Hillary Clinton was a flawed candidate and was not able to bring Bernie Sanders' supporters to her side when it mattered; vii) Wikileaks' mail leaks helped Trump; viii) the FBI investigation on Clinton's usage of a

Cristiano Lima, "Poll: Trump administration edges media in voter trust", Feb. 17, 2017, accessed Feb 27, 2017, http://www.politico.com/story/2017/02/trump-media-trust-poll-fox-news-235168; Julia R. Azari, "How the News Media Helped to Nominate Trump. Political Communication", Political Communication 33, 4 (2016): 677-680.

39 See "Polls-Plus Election Forecast", FiveThirtyEight, Nov. 8, 2016, accessed Feb. 23, 2017, https:// projects.fivethirtyeight.com/2016-election-forecast/\#plus.

${ }^{40}$ See R. Grim, "Nate Silver Is Unskewing Polls — All of Them — In Trump's Direction”, Huffington Post, Nov. 05, 2016, accessed Feb. 27, 2017, http://www.huffingtonpost.com/entry/nate-silverelection-forecast_us_581e1c33e4b0d9ce6fbc6f7f.

${ }^{41}$ See "Polls-Plus Election Forecast", FiveThirtyEight, Nov. 8., 2016, accessed Feb. 23, 2017, https:// projects.fivethirtyeight.com/2016-election-forecast/\#plus.

42 See D. Doyle, "Paddy Power's \$1 Million Gamble Backfires as Trump Upsets Odds", Bloomberg, Nov. 9, 2016, accessed Feb. 27, 2017, https://www.bloomberg.com/news/articles/2016-11-09/paddypower-s-1-million-gamble-backfires-as-trump-upsets-odds9/11/2016.

${ }^{43}$ An interesting story about Trump's pragmatism comes from the improbable of sources. In 2007, Vince McMahon - the husband of the Administrator of the Small Business Administration Linda McMahon - invited Trump to the biggest wrestling show on the world: Wrestlemania. Before the show, Vince asked Trump if we would allow the wrestler "Stone Cold Steve Austin" to hit him with a "Stone Cold Stunner", a wrestling move that targets the neck. After being assured that it would delight the crowd, Trump promptly accepted, ignoring the protests of his assistant. When reading this story one should not forget that even if wrestling is scripted injuries are usual and serious. Furthermore, Trump was a sexagenarian and not a trained athlete. See Tom Sheen, “OK, I'LL DO IT" How Donald Trump was convinced to take a Stone Cold Stunner by WWE supremo Vince McMahon”, The Sun, Jan. 21, 2017, accessed Feb. 24, 2017, https://www.thesun.co.uk/sport/2670864/donaldtrump-stone-cold-stunner-wrestlemania-wwe-vince-momahon/. 
personal server for governmental purposes and James Comey's declarations derailed her campaign. At the time of writing, no consensus has been reached and, since the issue is still sensitive in the American society, no consensus will be reached until proper historical detachment is possible.

In his campaign, Trump criticised mega-regional trade agreements that are, in his opinion, responsible for "stealing" American jobs. ${ }^{44}$ In his first week as President, he withdrew the USA from the Trans-Pacific Partnership (TPP). ${ }^{45}$ The USA was the biggest economy in the trade agreement and the main political force behind it. ${ }^{46}$ Without it, TPP's chances of survival are slim. The Transatlantic Trade and Investment Partnership (TTIP) between the USA and the EU (representing $46 \%$ of the World's GDP) will probably, at the least, suffer significant delays. The TTIP also faces criticism in the $\mathrm{EU}^{47}$ since Greenpeace leaked some secret documents related to its negotiations. ${ }^{48}$ European consumers are worried that the TTIP might degrade food safety, environmental standards ${ }^{49}$ and workers' rights ${ }^{50}$ in the name of free trade. ${ }^{51}$ The North American Free Trade Agreement (NAFTA), as promised by Trump, will be renegotiated. ${ }^{52}$

The Trump Administration wants to reduce the burden of "excessive" regulation on companies. Such reduction shall entail environmental deregulation and deregulation of the financial system. Despite only being in the first few months of the Trump administration, the President already signed executive orders related to these issues. ${ }^{53}$

\footnotetext{
${ }^{44}$ See S. A. Miller, "Trump vows to cancel Asia trade deal as president - and puts NAFTA on notice", Washington Times, Jun. 28, 2016, accessed Feb. 27, 2017. http://www.washingtontimes.com/news/2016/ jun/28/donald-trump-vows-to-cancel-trans-pacific-partners/.

45 See D. J. Trump, "Presidential Memorandum Regarding Withdrawal of the United States from the Trans-Pacific Partnership Negotiations and Agreement”, The White House, Jan. 23, 2017, accessed Feb. 27, 2017. https://www.whitehouse.gov/the-press-office/2017/01/23/presidential-memorandum-regardingwithdrawal-united-states-trans-pacific.

46 See D. Hamilton, "America's Mega-Regional Trade Diplomacy: Comparing TPP and TTIP", The International Spectator - Italian Journal of International Affairs, 49, 1, (2014): 81-97. J. Wilson, "MegaRegional Trade Deals in the Asia-Pacific: Choosing Between the TPP and RCEP?", Journal of Contemporary Asia, 45, 2, (2014): 345-353.

${ }^{47}$ See F. De Ville, G. Siles-Brügge, "Why TTIP is a game-changer and its critics have a point", Journal of European Public Policy, Online first (2016): 1-15.

${ }^{48}$ See Greenpeace, 2016, accessed 27 Feb. 27, 2017, https://ttip-leaks.org/.

49 See M. Karlsson, "TTIP and the environment: the case of chemicals policy", Global Affairs 1, 1, (2015): 21-31.

${ }^{50}$ See A. Tyc, "Workers' rights and transatlantic trade relations: The TTIP and beyond", The Economic and Labour Relations Review, 28,1, (2017): 113-128.

51 The Anti-Counterfeiting Trade Agreement (ACTA) was rejected by the European Parliament in 2012, after protests across the EU erupted due to the restrictions that the agreement would imposed on the European's freedom of expression and right to privacy. As a rule, European consumers are against the sacrifice of their personal freedoms in the name of free trade. See Andreas Dür and Gemma Mateo, "Public opinion and interest group influence: how citizen groups derailed the Anti-Counterfeiting Trade Agreement", Journal of European Public Policy 24,8 (2014): 1199-1217.

52 See A. Rascoe, "Trump to begin renegotiating NAFTA pact soon with Mexico, Canada", Reuters, Jan. 22, 2017, accessed Feb. 27, 2017, http://www.reuters.com/article/us-usa-trump-nafta-idUSKBN156128.

${ }^{53}$ See "Presidential Executive Order on Reducing Regulation and Controlling Regulatory Costs", Donald I. Trump, accessed Feb. 27, 2017, https://www.whitehouse.gov/the-press-office/2017/01/30/ presidential-executive-order-reducing-regulation-and-controlling; "Presidential Executive Order on Enforcing the Regulatory Reform Agenda", Donald J. Trump, accessed Feb 27, 2017, https://www. whitehouse.gov/the-press-office/2017/02/24/presidential-executive-order-enforcing-regulatoryreform-agenda; "Presidential Executive Order on Restoring the Rule of Law, Federalism, and
} 
Trump also promised a one trillion-dollar $\left(10^{12} \$\right)$ infrastructure plan..$^{54}$ These promises were received with enthusiasm by the financial markets, that are negotiating at record values. ${ }^{55}$ Other campaign promises from Trump may also affect the world's economy, like Trump's adversarial posture in relation to China ${ }^{56}$ and the ban on travellers from six (originally seven) ${ }^{57}$ Muslim-majority nations that are considered a threat to national security. Regarding the EU's internal integrity, Trump's support of Brexit and his apparent hostility against the EU and its leaders, and his declarations on NATO classifying it as obsolete followed by demands for further investment in defence from the allies caused discomfort amidst the European leaders. ${ }^{58}$ In response, the EU appears to be planning for a greater degree of military cooperation, in what could ultimately result in the creation of the European Army. ${ }^{59}$ With the UK leaving the EU it may be easier to achieve this goal since: $i$ ) France is now the only relevant military power in the EU and thus, it may be needed to safeguard the Union's safety; ii) the UK was always sceptic to the implementation of common defence policy. ${ }^{60}$

\section{Overcoming the existential crisis: a new chapter for the EU}

The EU never managed to completely overcome the collective trauma caused by the 2008 financial crisis. For one part, the economic recuperation was not as successful as in the US. The credibility of the EU's institutions was also seriously damaged. ${ }^{61}$

Economic Growth by Reviewing the "Waters of the United States" Rule", Donald J. Trump, accessed March 1, 2017, https://www.whitehouse.gov/the-press-office/2017/02/28/presidential-executiveorder-restoring-rule-law-federalism-and-economic.

${ }^{54}$ See Aric Jenkins, "President Trump Again Called for $\$ 1$ Trillion on Infrastructure — Without Many Details", Fortune, Mar. 1, 2017, accessed Mar. 1, 2017, http:/ fortune.com/2017/02/28/trumpcongress-address-infrastructure-investment.

55 See Caroline Valetkevitch, "Dow hits 12th record high close; Trump talks up infrastructure spending”, Reuters, Feb. 27, 2017, accessed Feb. 28, 2017, http://www.reuters.com/article/us-usastocks-idUSKBN1661KL.

${ }^{56}$ See E. Luce, "Donald Trump's collision course with China", Financial Times, Dec. 18, 2016, accessed Feb. 27, 2017, https://www.ft.com/content/5d9df7d4-c3c3-11e6-81c2-f57d90f6741a.

${ }^{57}$ The original executive order was replaced after a plethora of judicial challenges and defeats in State and Federal courts. The United States District Court for the Western District of Washington issued a temporary restraining order suspending its application and The United States Court of Appeals for The Ninth Circuit upheld the decision. At the time of writing, it is expected that the same States will challenge the new executive order on similar grounds, with support from Oregon, New York and Massachusetts. See, "Executive Order Protecting The Nation From Foreign Terrorist Entry Into The United States", Donald J. Trump, accessed Mar. 6, 2017, https://www.whitehouse.gov/the-pressoffice/2017/03/06/executive-order-protecting-nation-foreign-terrorist-entry-united-states; State of Washington v. Donald J. Trump [2017] (The United States District Court for the Western District of Washington); State of Washington v. Donald J. Trump [2017] (The United States Court of Appeals for The Ninth Circuit);

${ }^{58}$ See J. Masters, K. Hunt, “Trump rattles NATO with 'obsolete’ blast”, CNN, Jan. 17, 2017, accessed Feb. 27, 2017, http://edition.cnn.com/2017/01/16/politics/donald-trump-times-bild-interviewtakeaways/.

59 See J. Barigazzi, "EU backs greater military cooperation”, Politico, Nov. 15, 2016, accessed Feb. 24, 2017, http:/ /www.politico.eu/article/eu-backs-greater-military-cooperation-nato-donald-trumpfederica-mogherini/.

${ }^{6}$ See S. Besch, EU defence, Brexit and Trump: The Good, the Bad and the Ugly, (London: Centre for European Reform, 2016).

${ }^{61}$ In the span of 9 years, the confidence rating in the European institutions dropped from double digit positive values to negative values. In 2007, the European Parliament had a confidence rating of +28 , the Commission +24 and the Council of the European Union +19. In 2010, it had dropped to 
The Commission's "White Paper" might as well be called The Commission's "Blank Paper" since it lists five fictional scenarios but no single solution for the very real issue in the EU. In fact, when reading the White Paper, an old classic from Italian Cinema comes to mind. ${ }^{62}$ In Aprile, a semi-documental film from the Italian filmmaker Nanni Moretti, the main character (also played by Nanni Moretti) watches the 1996 Italian General Election televised debate between Silvio Berlusconi and Massimo D'Alema, the leader of the PDS. 'Berlusconi is attacking D' Alema whose passiveness and selfcontrol prompt Moretti to lose his patience and shout at the television: 'D' Alema, di qualcosa, reagiscil". ${ }^{63}$ Reading the "White Paper" incites the same reaction from the European citizen. An institution with the political influence and responsibility of the Commission should "say something, react"!

In May 2017, the French go to the polls in the Presidential elections. The Eurosceptic candidate Marine Le Pen is an almost certain lock for disputing the second round of the elections. Even if it is unlikely that she will ultimately achieve victory, the same was said of Donald Trump. In the Netherlands, Geert Wilders' PVV might become the largest political party in the Tweede Kamer (lower chamber of the Dutch Parliament). While it is almost certain that PVV will not be able to form a government because they will not achieve the required majority and do not have the support of other parties, ${ }^{64}$ such a result should be cautiously noted. In Germany, the dispute will be between Merkel's CDU and Schulz SPD, none of them being an immediate risk to European integrity. Even so, AfD's evolution in recent years is worrisome. ${ }^{65}$ In Italy, Beppe Grillo's M5S was one of the largest contributors to the defeat of government's proposal in the constitutional referendum and the subsequent resignation of the Prime Minister Matteo Renzi. From the analysis done of the referendum in the UK and the American Presidential election it can be submitted that the political forces that wish for the disintegration of the EU have a lot of defects, but no one needs to tell them "di qualcosa, reagiscip".

Now is the time to reform the EU. If we wait any longer, there might be no turning back. The most powerful European politics cannot keep watching, in apathy, the ongoing disintegration of the EU. The confidence of the citizens in the European institutions must be won again and this will not be possible unless the current organisation of the institutions is also reformed, as we and the referred resolutions of

+11 for the Parliament, +9 for the Commission and +5 for the Council of the European Union. In 2016, the value was of -6 for the Parliament and -8 for the Commission, with no data published for the Council of the European Union. See "Eurobarometer 68 - Public Opinion in the European Union", European Commission, accessed Mar. 1, 2017; http:/ / ec.europa.eu/commfrontoffice/publicopinion/ archives/eb/eb68/eb_68_en.pdf; "Eurobarometer 73 - Public Opinion in the European Union”, European Commission, accessed Mar 1, 2017, http://ec.europa.eu/public_opinion/archives/eb/ eb73/eb73_vol1_en.pdf; "Eurobarometer 85 - Public Opinion in the European Union”, European Commission, accessed Mar. 1, 2017, http://ec.europa.eu/COMMFrontOffice/publicopinion/index. cfm/ResultDoc/download/DocumentKy/75977.

${ }^{62}$ See Aprile. (1998). [DVD] Italy: Nanni Moretti.

${ }^{63}$ See G. Bonsaver, "The egocentric Cassandra of the left: Representations of politics in the films of Nanni Moretti”, The Italianist, 21,1 (2011): 158-183.

${ }^{64}$ See R. Korteweg, "Double Dutch: Why Wilders Wins, Even If He Stays Out of Government", Centre for European Reform. Mar. 3, 2017, accessed March 3, 2017, https://www.cer.org.uk/insights/ double-dutch-why-wilders-wins-even-if-he-stays-out-government.

${ }^{65}$ Even if the party seems to be losing support and donations in the aftermath of Björn Höcke's declarations on the Holocaust. See Severin Weiland, "AfD sinkt in Umfragen. Angst bei den Angstmachern”, Der Spiegel, Feb. 27, 2017, accessed Feb 27, 2017, http://www.spiegel.de/politik/ deutschland/afd-brandbrief-der-afd-landeschefs-an-die-basis-a-1136479. 
the European Parliament suggested above. If doing so entails a revision of European Constitutional law, (the TUE and TFUE) then so be it.

There is no future in an "economic giant" that is simultaneously a "political dwarf". ${ }^{60}$

${ }^{66}$ F. Quadros, Direito da União Europeia, (3 ${ }^{\text {rd }}$ ed. Coimbra: Almedina, 2013): 717. 